\title{
PERUBAHAN MASYARAKAT PASCA PENGGUNAAN ALAT BERAT PADA PERTAMBANGAN PASIR DI DESA KENINGAR
}

\author{
Arif Miftah ${ }^{1}$, Supriyadi ${ }^{2}$ \\ Program Studi Sosiologi Fakultas Ilmu Sosial dan Politik \\ Universitas Sebelas Maret Surakarta Indonesia \\ Email: arifmiftah@student.uns.ac.id ${ }^{1}$,supriyadi.sn.su@gmail.com²
}

\begin{abstract}
Sand mining with heavy equipment entered in Keningar Village manuai pros and cons in the community. The conflict between the two groups has had an impact on the changing sub-life of keningar village people. The purpose of this research is to find out how post-mining society changes with heavy equipment on the structure of society, culture, economy, environment, security of public order. And see how heavy equipment usage impacts that sub-life. The research method used is qualitative with the Naturalistic Inquiry approach. The sampling technique used is purposive sampling. Data collection is conducted with interviews, observations, and documentary studies. Lewis conflict theorists Alfred Coser and Ralf Dahrendorf were used to examine how the details of the conflict in Keningar occurred, as well as try to see the changing society in Keningar. The results showed that there were changes in the structure of rural communities, the emergence of a new middle class and the occurrence of social differentiation in the profession. Cultural changes including weak community solidarity are now strengthening again, the distorted culture and consumerism that once existed is now disappearing. The economic condition of the people, particularly incomes, has decreased. The natural environment in Keningar is changing, as village road conditions get better, air pollution and noise no longer exist. But heavy mining leaves damage to former mines, irrigation is disrupted by declining water discharge and water clarity. Public safety and order improved, reduced sandbags in and out of the village gave road users a sense of security, the thugism that once grew now no longer exists, drinking habits and prostitution activities in minefields are no longer found. But now the risk of accidents for manual miners is very high. The use of heavy equipment has a positive impact on the changing structure of society and the citizen economy. But less good on the environment, culture, security of keningar village community order.
\end{abstract}

Keywords: mining, heavy equipment, conflict, changing society

Abstrak: Pertambangan pasir dengan alat berat yang masuk di Desa Keningar manuai pro
dan kontra dalam masyarakat. Konflik antar dua golongan berdampak pada perubahan sub
kehidupan masyarakat Desa Keningar. Tujuan penelitian ini untuk mengetahui bagaimana
perubahan masyarakat pasca pertambangan dengan alat berat pada struktur masyarakat,
kebudayaan, ekonomi, lingkungan, keamanan ketertiban masyarakat. Serta melihat
bagaimana dampak penggunaan alat berat pada sub kehidupan tersebut. Metode penelitian
yang digunakan yaitu kualitatif dengan pendekatan Naturalistic Inquiry. Teknik sampling
yang digunakan adalah purposive sampling. Pengumpulan data dilakukan dengan
wawancara, observasi, dan studi dokumenter. Teori konflik Lewis Alfred Coser dan Ralf
Dahrendorf digunakan untuk mengkaji bagaimana detail konflik di Keningar itu terjadi,
serta mencoba melihat perubahan masyarakat di Keningar. Hasil penelitian menunjukan
bahwa terdapat perubahan struktur masyarakat desa, munculnya kelas menengah baru dan
terjadinya deferensiasi sosial dalam profesi. Perubahan budaya meliputi solidaritas 
masyarakat yang lemah kini menguat kembali, budaya menyimpang dan konsumerisme yang dahulu ada kini menghilang. Kondisi ekonomi masyarakat terkhusus pendapatan mengalami penurunan. Lingkungan alam di Keningar mengalami perubahan, seperti kondisi jalan desa semakin baik, polusi udara dan suara tidak lagi ada. Namun pertambangan dengan alat berat menyisakan kerusakan pada lahan bekas tambang, pengairan masyarakat terganggu dengan menurunnya debit air dan tingkat kejernihan air. Keamanan dan ketertiban masyarakat membaik, berkurangnya truk muatan pasir yang keluar masuk desa memberi rasa aman pengguna jalan, premanisme yang dahulu tumbuh kini tidak lagi ada, kebiasaan minum-minuman keras dan kegiatan prostitusi di lahan tambang tidak lagi ditemukan. Namun kini resiko kecelakaan bagi penambang manual sangat tinggi. Penggunaan alat berat berdampak positif pada perubahan struktur masyarakat dan perekonomian warga. Namun kurang baik pada lingkungan, budaya, keamanan ketertiban masyarakat Desa Keningar.

Kata kunci: pertambangan pasir, alat berat, konflik, perubahan masyarakat

\section{PENDAHULUAN}

Indonesia secara geografis terletak pada kawasan cincin api (ring of fire), yaitu lokasi yang sering mengalami bencana gempa bumi dan letusan gunung berapi (Akbar et.al, 2018). Hal ini dibuktikan dengan banyaknya jumlah gunung api yang masih aktif maupun tidak aktif di Indonesia, terutama di bentang Pulau Sumatra, Pulau Jawa, Pulau Bali, Kepulauan Nusa Tenggara, hingga Pulau Maluku. Menurut Kementrian Energi dan Sumber Daya Mineral (ESDM) Indonesia memiliki 500 gunung api yang dimiliki, yang mana 127 diantaranya masuk dalam kategori aktif (https://www.esdm.go.id, diakses pada tanggal 28 November 2019).

Pulau Jawa masuk dalam daftar pulau yang memiliki gunung api aktif hingga dewasa kini. Gunung Merapi merupakan salah satu kategori gunung api yang aktif diantara 127 gunung api yang terdata di seluruh Indonesia. Gunung Merapi terletak di Kabupaten Sleman dan terbagi ke dalam beberapa wilayah lainnya. Sebelah selatan termasuk wilayah Kabupaten Sleman Provinsi Daerah Istimewa Yogyakarta. Sebelah Utara termasuk wilayah Kabupaten Boyolali. Sebelah barat termasuk dalam wilayah Kabupaten Magelang, dan sebelah timur termasuk wilayah Kabupaten Klaten (Asriningrum, 2004).

Gunung Merapi memiliki kekayaan alam yang sangat melimpah, seperti pasir, batu, kesuburan tanah, persediaan air, dan lain sebagainya. Pasir merupakan salah satu produk kegiatan Gunung Merapi yang menjadi andalan pemerintah Kabupaten Magelang dalam meningkatkan Pendapatan Asli Daerah (PAD) dan juga menyerap lapangan kerja. Selain mendatangkan manfaat penambangan pasir Gunung Merapi juga menimbulkan dampak lingkungan bagi daerah (Yudhistira, 2011).

Gunung Merapi memiliki dua sisi potensi, yakni potensi sumber daya alam yang menguntungkan dan potensi bahaya yang cenderung merugikan kehidupan. Keberadaan Gunung Merapi beresiko terhadap keamanan dan keselamatan masyarakat maupun alamnya. Bahaya primer Gunung Merapi bahaya yang langsung menimpa penduduk ketika letusan berlangsung, misalnya, awan panas, gempa bumi, udara panas sebagai akibat samping awan panas, dan lontaran material berukuran blok (bom) hingga kerikil. Sedangkan bahaya sekunder terjadi secara tidak langsung dan umumnya berlangsung setelah letusan letusan terjadi, seperti lahar dingin yang dapat menyebabkan kerusakan lahan dan pemukiman (Rahayu et.al, 2014). 
Selain itu, resiko terancamnya keamanan dan keselamatan masyarakat dapat juga timbul akibat perilaku manusia. Salah satu contoh riil yang sering terjadi adalah masalah pertambangan. Kegiatan pertambangan merupakan usaha pemanfaatan sumber daya alam. Kegiatan ini dapat dilakukan pada alam yang mempunyai atau mengandung cadangan mineral ataupun bahan galian lainnya (Ma'rifah, 2014).

Dilematika masyarakat terhadap kegiatan pertambangan sedikit demi sedikit tumbuh akibat banyaknya perilaku penambang yang tidak pertanggung jawab dan tak berwawasan lingkungan. Sekitar 70 persen kerusakan lingkungan di Indonesia disebabkan oleh operasi pertambangan (Kompas.com - 28/09/2012, diakses pada tanggal 28 November 2019). Fakta tersebut menggambarkan bahwa alam sebagai sumber kehidupan yang melahirkan berbagai kebutuhan manusia kini dipertanyakan kondisinya.

Pasir atau bahan galian $\mathrm{C}$ merupakan salah satu kekayaan alam yang dimiliki oleh Gunung Merapi, memiliki daya tarik yang sangat tinggi terutama bagi para penambang pasir. Watak penambang eksploitatif yang tidak berwawasan lingkungan membawa kekhawatiran tinggi bagi masyarakat. Pemanfaatan kekayaan alam yang berlebihan secara langsung akan memberi dampak negatif bagi kehidupan masyarakat. Dewasa ini menjadi miris melihat sikap penambang yang eksploitatif. Terlebih lagi kini maraknya pertambangan tanpa izin.

Dilematika tersebut terus menerus tumbuh dalam masyarakat hingga berujung pada pro dan kontra atas pertambangan. Kegiatan pertambangan sangat beresiko terhadap keseimbangan lingkungan, baik lingkungan fisik maupun lingkungan sosial. Oleh karena itu, sektor pertambangan penting dikaji karena kegiatan pertambangan di Indonesia sering menimbulkan konflik (Ma'rifah, 2014). Pertambangan secara pasti akan merusak lingkungan, namun disisi lain pertambangan juga dibutuhkan guna menambah pendapatan masyarakat, mengurangi pengangguran, dan sebagai pemasukan negara. Bermula dari hal tersebut maka perlu ada suatu cara dimana konsep keadilan lingkungan dijunjung tinggi. Bijaksana dalam memanfaatkan lingkungan dapat meminimalisir gejolak yang ada. Di Indonesia perjuangan menegakkan keadilan lingkungan terus digalakkan. Berbagai perlawanan terus dilakukan (Siswono, 2015).

Secara etika lingkungan hubungan manusia terhadap lingkungan mempunyai kewajiban moral dan tanggungjawab terhadap makhluk hidup lainnya (Mufid, 2010). Kabupaten Magelang merupakan salah satu dari beberapa kabupaten di Jawa Tengah yang memiliki kekayaan alam cukup tinggi. Keberadaan Gunung Merapi menjadi salah satu nilai tambah bagi Kabupaten Magelang dalam mengakumulasikan aset alam. Gunung Merapi menyimpan kekayaan alam yang melimpah seperti pasir, batu, dan kesuburan tanahnya. Fakta tersebut menjadikan Magelang sebagai salah satu supplayer bahan-bahan material ke berbagai daerah.

Desa Keningar merupakan salah satu desa dikawasan Gunung Merapi yang mempunyai potensi alam (pasir dan batu) yang tinggi, karena berdekatan dengan Gunung Merapi. Keberadaan pasir dan batu di Keningar secara langsung berdampak pada seluruh sub kehidupan, terutama pada segi ekonomi masyarakat desa. Selain menjadi petani dan berkarir di dunia swasta, masyarakat Keningar juga turut menikmati kekayaan alam yang ada, yakni sebagai buruh tambang. Sebelum menggunakan alat berat, pertambangan di Keningar dilakukan secara manual oleh masyarakat sekitar. Masuknya alat berat menuai problematika yang cukup besar di masyarakat. Pro dan kontra terhadap penggunaan alat berat tersebut bermunculan seiring berjalannya waktu. Berdasarkan penelitian yang dilakukan oleh Dheva Vembyawan Rahadi tahun 2018 tantang Dampak Ekonomi dan Lingkungan dari Aktivitas Pertambangan Pasir Di Kabupaten Magelang Pasca Penghapusan Peraturan Daerah Kabupaten Magelang Nomor 1 Tahun 2008. dapat 
diketahui bahwa dari segi ekonomi dan lingkungan keberadaan aktivitas pertambangan sangat berpengaruh.

Penelitian ini bermaksud untuk menggali lebih dalam tentang perubahan masyarakat Desa Keningar pasca penggunaan alat berat beserta dampaknya. Mencoba melihat dan menarasikan perubahan yang terjadi di dalamnya. Cangkupan perubahan masyarakat Keningar yang akan di dalami terbagi menjadi lima sub bagian, yakni struktur masyarakat, budaya, ekonomi, lingkungan, dan kamtibmas.

\section{METODE PENELITIAN}

Penelitian ini dilakukan di Desa Keningar, Kecamatan Dukun, Kabupaten Magelang. Jenis penelitian yang digunakan dalam penelitian ini adalah penelitian deskriptif. Penelitian deskriptif dipakai dengan tujuan untuk medeskrispikan fenomena pertambangan pasir di Desa Keningar Kecamatan Dukun Kabupaten Magelang. Metode penelitian yang digunakan dalam penelitian ini adalah kualitatif. Bogdan dan Taylor dalam Moleong (2014) menyatakan bahwa penelitian kualitatif merupakan penelitian yang menghasilkan data deskriptif berupa kata-kata tertulis atau lisan dari orang-orang dan perilaku yang dapat di amati, dengan melakukan penafsiran terhadap fenomena yang sedang terjadi. Pendekatan yang akan digunakan dalam penelitian ini adalah nartralistic inquiry (NI). Paradigma naturalistik menyatakan bahwa peneliti dan objek yang di teliti harus bersifat interaktif dan tidak dapat dipisahkan. Teknik sampling yang digunakan adalah Purposive Sampling atau sampling bertujuan. Teknik ini digunakan dengan alasan sesuai dengan tujuan penelitian. Sampel yang akan digali informasinya harus sesuai dengan syarat yang ditentukan sebelumnya. Menurut Idrus (2009) Purposive Sampling adalah teknik sampling yang menentukan pertimbangan-pertimbangan tertentu dalam pengambilannya. Semua itu dilakukan agar keefektifan dan efisiensi penelitian dapat terjamin. Teknik penggumpulan data dilakukan dengan dengan wawancara, observasi, dan teknik/studi dokumenter. Dalam menguji kevalidan atau keabsahan data penalitian peneliti menggunakan teknik Triangulasi. Menurut Moleong (2014) triangulasi adalah teknik pemeriksaan keabsahan data yang memanfaatkan sesuatu yang lain. Istilahnya hal ini dilakukan untuk menguatkan atau mencari kebenaran dari data yang didapatkan. Penelitian ini menggunakan teknik triangulasi sumber dan triangulasi metode. Teknik analisis data yang digunakan dalam penelitian ini sebagaimana ide digagas oleh Mils dan Huberman. Dalam Silalahi (2009) Mils dan Huberman menjelaskan, terdapat tiga alur kegiatan dalam menganalisis data, yakni reduksi data, penyajian data, dan penarikan kesimpulan atau verifikasi.

\section{HASIL DAN PEMBAHASAN}

Pertambangan pasir menjadi salah satu penopang kehidupan ekonomi warga Desa Keningar. Pertambangan pasir menjadi mata pencaharian baru disela-sela kegiatan bertani dan mencari kayu bakar di hutan. Pada mulanya pertambangan disambut positif oleh warga desa, karena cenderung menguntungkan secara ekonomis dari pada bertani atau pun mencari kayu bakar. Beberapa posisi yang bisa ditempati warga di pertambangan, sebagai pengelola pertambangan, sebagai operator alat berat, helper atau kernet alat berat, mekanik alat berat, penjaga karcis, buruh coker atau perata pasir di armada pengangkut bahan galian $\mathrm{C}$, dan ada pula yang berpofesi sebagai penjaga alat berat di malam hari.

Seriring berjalannya waktu kondisi pertambangan di Keningar mengalami perubahan. Berakar dari keberadaan alat berat yang secara masif mengeksploitasi lahan dari tahun 1999 sampai dengan 2014. Eksploitasi alam yang berlebihan ternyata membuat 
kenyamanan masyarakat desa terusik. Hal tersebut memicu adanya sekelompok warga untuk melakukan perlawanan, dalam wadah Forum Pelindung Hak dan Aset Desa (FORPHAS) dan pada tahun 2011 berubah nama menjadi TIM 18. TIM 18 bersama masyarakat berusaha memperjuangkan keadilan lingkungan dengan berbagai cara seperti demonstrasi, pembuatan portal jalan, sistem tonase, pembuatan surat pengaduan atas aktivitas tambang, hingga kegiatan pengusiran kegiatan pertambangan di daerah-daerah larangan tambang.

Dewasa kini alat berat yang digunakan untuk menambang telah berhenti beroperasi dan keluar dari jangkauan masyarakat Desa Keningar, begitu juga para pengusaha dan oknum penambang ilegal lainnya. Pertambangan yang tersisa di Desa Keningar kini hanya pertambangan manual dengan alat seadanya. Dinamika pertambangan di Keningar yang bermasalah tersebut memberikan efek pada perubahan struktur masyarakat, budaya, ekonomi, lingkungan, dan kemanan ketertiban masyarakat desa.

\section{a. Perubahan Struktur Masyarakat}

Struktur masyarakat Desa Keningar mengalami perubahan. Perubahan sturktur masyarakat yang dapat diamati berupa perubahan horizontal (differensiasi) maupun secara vertikal (stratifikasi). Perubahan secara horizontal yang ditemukan dalam masyarakat adalah perubahan profesi atau mata pencaharian warga desa. Sebelum alat berat masuk ke Keningar, mata pencaharian warga mayoritas petani dan pencari kayu bakar di hutan. Namun setelah pertambangan dengan alat berat ada, mata pencaharian masyarakat berubah. Profesi awal yang mayoritas petani atau buruh tani beralih menjadi buruh tambang. Walaupun masih ada beberapa petani yang menggantungkan hidupnya di pertanian. Hal yang berbeda ditemui pada kondisi pasca pertambangan dengan alat berat tidak ada. Kurang lebih akhir tahun 2014 dan awal 2015, alat berat atau beck how sudah tidak digunakan di pertambangan Keningar.

Banyak masyarakat desa yang kehilangan pekerjaannya di pertambangan, terutama buruh coker. Sub pekerjaan di pertambangan cukup beragam seperti menjadi operator alat berat, kernet alat berat, mekanik alat berat, penjaga karcis, buruh coker, dan penjaga alat berat. Pekerja yang memiliki spesialisasi tertentu seperti operator, kernet, dan mekanik alat berat, mereka masih menduduki posisi aman. Saat ini mereka bekerja di pertambangan pasir di luar Keningar. Namun ada pula yang melanjutkan kegiatan pertambangannya di Keningar, hanya saja dilakukan secara manual di tanahnya sendiri. Selebihnya dari pada itu mereka kembali lagi ke profesi awal, yakni bertani, buruh serabutan.

Perubahan secara vertikal juga terlihat seperti, munculnya kelas pekerja yang memiliki spesialisasi, munculnya juragan baru, dan perubahan status pekerja tambang menjadi aparat desa. Pertama, munculnya kelas pekerja yang memiliki spesialisasi. Masyarakat desa yang awalnya menjadi buruh biasa di lahan pertambangan, seiring berjalannya waktu kedudukan mereka berpindah ke arah pekerjaan yang memiliki spesialisasi. Para kernet alat berat yang berpindah posisi sebagai operator alat berat di pertambangan. Kedua, kemunculan juragan baru dikalangan masyarakat. Juragan baru yang dimaksud adalah pemilik usaha depo pasir. Pemilik depo pasir tersebut dahulunya berkerja sebagai penambang manual batu dan sebagai operator alat berat di lahan pertambangan, pasca pertambangan dengan alat berat berhenti warga tersebut mulai merintis usaha depo pasirnya. Ketiga, Perubahan status sosial ketiga adalah perubahan status warga desa yang semula bekerja sebagai buruh tambang, kini menjabat sebagai aparat desa. Hal ini bermula dari keberadaan TIM 18 yang bercita-cita mengisi perpolitikan desa dan hendak memberikan pengaruh terhadap kebijakan desa, dengan mengisi Badan Permusyawaratan 
Desa (BPD). Alasan tersebut diangkat karena TIM 18 beranggapan pemerintah desa kurang responsif terhadap pengambilan kebijakan yang berkaitan dengan masalah pertambangan.

\section{b. Perubahan Budaya Masyarakat Desa Keningar}

Perubahan budaya yang terlihat di Keningar disebabkan oleh dua hal yakni konflik internal dalam masyarakat (antara warga pro dan kontra rambang) dan pengaruh masyarakat pendatang pada saat pertambangan dengan alat berat beroperasi. Perubahan yang terjadi dalam lingkup budaya desa dapat dikategorikan menjadi tiga hal. Pertama, perubahan solidaritas masyarakat. Adanya pro dan kontra dalam satu wilayah membuat beberapa kegiatan yang melibatkan masa banyak terganggu solidaritanya. Kelompok seni yang ada di Keningar vakum akibat adanya dua golongan masyarakat tersebut, hingga ada satu kesenian jatilan mati dan tidak hidup lagi hingga sekarang. Kegiatan gotong royong desa, seperti sambatan pembangunan rumah atau sambatan dalam kegiatan pertanian juga terganggu. Timbulnya pengkotak-kotakan posisi berkumpul. Tradisi rutinan desa seperti kenduri, sadranan, suronan, slametan untuk bayi (momong, mitoni, dan tingkepan), merti dusun atau auman, ruwahan, badhan, slametan kematian. Kehidupan tradisi ini masyarakat mengalami pengkotak-kotakan sebagaimana dalam realitas budaya gotong royong. Hal yang berbeda ditemui pasca pertambangan dengan alat berat berhenti dari operasinya. Masyarakat desa semakin kuat solidaritanya baik di kehidupan seni, gotong royong, dan tradisi rutinan desa, atrinya solidaritas masyarakat kembali seperti dulu lagi. Namun ada beberapa budaya yang hilang seperti budaya sambatan dalam hal pertanian dan kesenian Jatilan Krido Sentono.

Kedua, masuknya budaya asing ke Desa Keningar. Budaya asing tersebut adalah makin banyaknya warga desa yang mengenal dan mengkonsumsi minuman keras (miras), induvidualisme, hingga prostitusi. Budaya menyimpang tersebut saat ini saat ini tidak ditemukan kembali. Ketiga, masuknya pendatang dari berbagai daerah dan tingginya pendapatan warga masyarakat Keningar saat bekerja di pertambangan, mengundang prilaku konsumsi yang berlebihan (konsumerisme). Perilaku konsumerisme berupa kegemaran pergi ke tempat hiburan malam untuk karaoke, membeli barang mewah (mobil), membeli miras, dan datang ke tempat prostitusi. Kondisi pasca pertambangan alat berat dan masyarakat luar pergi dari Keningar, budaya konsumtif tersebut tidak terlihat lagi.

\section{c. Perubahan Ekonomi Masyarakat Desa Keningar}

Pengaruh pertambangan pasir terhadap ekonomi warga berupa peningkatan pendapatan, terutama bagi pekerja tambang. Baik itu sebagai operator alat berat, coker, dan lainnya. Hal tersebut juga menjadi alasan banyaknya petani dan buruh tani memilih bekerja di pertambangan dari pada di sawah atau di ladang. Naiknya pendapatan warga dibarengi dengan bertambah banyaknya kekayaan yang dimiliki. Hasil pendapatan pekerja tambang secara umum selain untuk kebutuhan sehari-hari oleh mereka digunakan untuk membeli mobil, sepeda motor, perhiasan/emas, lahan, dan tentunya untuk membangun rumah. Walaupun di sekitar kawasan pertambangan terdapat Usaha Mikro Kecil Menengah (UMKM) milik warga desa seperti warung kelontong dan usaha pencucian kendaraan, yang sebenarnya sangat potenisal terdampak. Namun berdasarkan pengakuan pelaku usaha, usahanya tidak terkena imbas apapun oleh ramainya kegiatan pertambangan

Kondisi ekonomi pekerja tambang meningkat pesat, namun hal yang berbeda ditemui pada tahun-tahun selanjutnya, yakni tahun dimana pertambangan dengan alat berat tidak lagi beroperasi di Keningar. Secara otomatis masyarakat kehilangan pekerjaannya. Mayoritas eks pekerja tambang kembali lagi bekerja di pertanian, sebagian kecil masih bekerja di petambangan (hanya saja tidak di Desa Keningar), pekerja serabutan, dan beberapa warga menganggur. Hal itu membuat pendapatan mereka menurun. Namun untuk 
memenuhi kebutuhan sehari-hari masayarakat eks penambang tetap merasa kecukupan. Hampir semua kekayaan kemewahan yang didapat dari bekerja di pertambangan seperti mobil, perhiasan, lahan dijual kembali kecuali rumah. Begitu juga dengan kebiasaan hedonisme yang ada di masyarakat, pasca pertambangan dengan alat berat tidak terlihat lagi.

\section{d. Perubahan Lingkungan Masyarakat Desa Keningar}

Kegiatan tambang dengan alat berat merubah seluruh tatanan alam yang semula rindang dan asri, kini menjadi rusak parah. Kerusakan lingkungan yang terjadi antara lain sebagai berikut. Pertama, Kerusakan jalan desa. Kondisi jalan desa semula rusak parah, yakni sebelum tahun 2011 atau sebelum erupsi Merapi. Dewasa kini telah membaik, perbaikan tersebut dilakukan oleh Dinas Pekerja Umum (PU) pada tahun 2011 (pasca erupsi Merapi). Kedua, Munculnya polusi udara dan suara. Polusi udara bersumber dari asap kendaraan pengangkut bahan galian $\mathrm{C}$ dan debu jalanan. Debu dan asap kendaraan yang dibawa oleh truk-truk pengangkut dari lahan pertambangan dan menyebar di setiap jalan yang dilaluinya. Sedangkan polusi suara timbul dari suara truk bahan galian $\mathrm{C}$ yang bising. Karena beroperasi selama 24 jam penuh. Ketiga, Pengairan warga terganggu. Jangkauan masalah pengairan warga melingkupi kerusakan saluran irigasi, kondisi air di irigasi menjadi keruh, dan matinya sumber mata air. Kerusakan irigasi berupa aliran air terputus dan mati akibat ditambang. Selain itu, air yang irgasi tersebut menjadi keruh akibat terkena debu dan Bahan Bakar Minyak (BBM) dari alat berat di lahan pertambangan (pertambangan pasir di Sungai Senowo). Keempat, Kerusakan lahan bekas tambang. Lahan tambang yang dahulu hijau oleh pepohonan dan tanaman pertanian. Kini kontras dengan keadaan sebelumnya, hal ini terjadi karena aktivitas pertambangan pasir dengan alat berat. Pasca pertambangan dengan alat berat selesai, lahan bekas tambang tidak mendapat perbaikan ulang. Lahan bekas tambang yang luasnya kurang lebih 50 hektar kini terbengkalai dan penuh dengan kubangan yang curam. Berisi tumpukan batu, gersang, dan tidak bisa ditanami tanaman.

Kondisi lingkungan terkini seperti kerusakan jalan, polusi suara dan udara sudah tidak ditemukan lagi. Namun jejak pertambangan pasir dengan alat berat di Keningar menyisakan matinya salah satu dari beberapa sumber mata air yang ada dan rusaknya lingkungan alam bekas pertambangan.

\section{e. Perubahan keamanan dan ketertiban masyarakat (Kamtibmas) Desa Keningar}

Keamanan dan ketertiban masyarakat terganggu semenjak pertambangan dengan alat berat masuk ke Desa Keningar. Masuknya pertambangan dengan alat berat, secara langsung membawa pengaruh yang berbeda pada sistem ketertiban dan keamanan desa. Anomie terjadi waktu pertambangan dengan alat berat ada. Masyarakat pendatang secara perlahan mengenalkan budaya asing yang cenderung menyimpang kepada penduduk lokal, terutama masyarakat yang bekerja di lahan pertambangan. Bermula dari hal tersebut, masyarakat mengenal minuman keras (miras) dan prostitusi. Selain itu, pelanggaran akan aturan juga sering terjadi. Terutama oleh sopir truk bahan galian $\mathrm{C}$. Masyarakat telah mensosialisasikan pemberlakukan jam kerja portal, yakni dibuka jam 6 pagi dan tutup jam 6 sore. Namun ada saja supir yang belum keluar dari desa sesuai jam portal tersebut. Kondisi pasca pertambangan dengan alat berat tidak ada lagi di Keningar secara otomatis membawa keluar kembali budaya-budaya menyimpang yang mengganggu ketertiban.

Selanjutnya berkaitan dengan keamanan Desa Keningar. Tidak jauh berbeda dengan fenomena diatas, tentang ketertiban. Keamanan warga desa terganggu saat keberadaan pertambangan dengan alat berat tengah ramai. Bentuk gangguannya adalah merasakan tidak 
nyaman saat menggunakan jalan utama desa, karena banyak truk muatan pasir yang berlalulalang hingga ugal-ugalan. Selain itu, rasa aman masyarakat juga semakin berkurang karena gangguan preman tambang. Preman tambang yang bertugas memperlancar aktivitas pertambangan kerap kali mengintervensi warga yang menghambat dengan ancaman kriminal. Pasca pertambangan dengan alat berat berhenti. Keramaian jalan desa oleh armada bahan galian $\mathrm{C}$ semakin berkurang. Kondisi jalan desa semakin ramah terhadap aktivitas warga, baik anak-anak maupun orang dewasa. Begitu juga premanisme yang dahulu terjadi, pasca pertambangan dengan alat berat berhenti preman-preman tersebut turut keluar dari desa.

Keamanan di lahan pertambangan. Resiko kecelakaan saat berada di lokasi pertambangan sangat tinggi, baik bagi pekerja tambang maupun anak-anak yang sedang bermain di lahan pertambangan. Realitas mengatakan demikian, banyak pekerja tambang yang kecelakaan saat bekerja. Seperti tertimpa batu dari atas truk maupun terjatuh saat bekerja menjadi coker. Resiko bagi anak-anak juga mengkhawatirkan karena dahulu banyak anak-anak yang bermain di lokasi pertambangan dan ada juga anak anak yang kerja di lahan pertambangan. Resiko yang dikhawatirkan warga adalah longsor. Saat pertambangan dengan alat berat masih beroperasi pernah terjadi kematian anak di lahan pertambangan karena tenggelam dalam kubangan bekas pertambangan. Kondisi pasca pertambangan dengan alat berat berhenti, resiko kecelakaan masih juga tinggi. Terutama bagi penambang manual, banyak korban longsor dari aktivitas tersebut. Resiko bagi anakanak tidak ada, karena pasca pertambangan dengan alat berat berhenti, anak-anak tidak lagi bermain di lokasi tambang.

\section{f. Dampak Pertambangan dengan Alat Berat Pasir di Desa Keningar}

Penggunaan alat berat di keningar memberikan dampak pada seluruh sub kehidupan masyarakat, baik di struktur masyarakat, budaya, ekonomi, lingkungan, dan keamanan ketertiban masyarakat.

\section{Dampak pada struktur masyarakat.}

Masyarakat desa mengalami perubahan struktur baik vertikal maupun horizontal. Perubahan status vertikal terjadi pada naiknya beberapa buruh tambang yang memperjuangkan lingkungan ke jajaran pemerintahan desa, munculnya kelas pekerja yang memiliki spesialisasi (operator alat berat), dan munculnya juragan baru (pemiliki depo pasir). Sedangkan perubahan secara horizontal dapat diamati pada munculnya pekerjaan baru sabagi buruh tambang yang semula tidak ada. Para pertani memilih menjadi buruh tambang dari pada bertani, sehingga berakibat pada susahnya mencari pekerja tani di Desa Keningar.

\section{Dampak pada budaya masyarakat.}

Budaya masyarakat desa luntur akibat konflik antar masyarakat pro kontra tambang dan akibat masayarakat pendatang yang bekerja di lahan pertambangan, baik menetap atau hanya pekerja sebatas singgah untuk bekerja. Dampak yang dapat diamati sebagai berikut : pertama, menurunnya solidaritas warga. Penurunan solidaritas terjadi di dunia kesenian, budaya gotong-royong atau sambatan, dan dalam tradisi rutinan desa. Secara umum terjadi pengkotak-kotakan posisi berkumpul dan minimnya partisipasi dalam kegiatan. Hal ini terjadi karena perbedaan cara pandag antar masyarakat dan keinginan untuk menenambang lebih tinggi dari pada berkumpul. Kedua, Masuknya budaya menyimpang seperti, kebiasaan minum-minuman keras dan porstitusi. Ketiga, masuknya budaya konsumerisme di kalangan warga akibat pengaruh masyarakat luar. Budaya tersebut berupa barang mewah, seperti 
mobil pribadi, beberapa motor baru, dan perhiasan emas, sering menghabiskan uangnya ke tempat hiburan malam atau tempat karaoke hingga ke tempat pelacuran.

\section{Dampak pada perekonomian warga desa}

Pertambangan pasir dengan alat berat berdampak positif pada perekonomian warga, terutama warga yang bekerja di lahan pertambangan. Mayoritas dahulu masyarakat Keningar berprofesi sebagai petani maupun buruh tani. Semenjak pertambangan dengan alat berat masuk desa, masyarakat desa yang awalnya bertani mulai beralih ke pertambangan. Posisi warga desa di pertambangan cukup beragam, ada yang sebagai operator alat berat, coker, helper, mekanik alat berat, jaga malam, dan jaga karcis. Pindahnya konsentrasi kerjaan masyarakat desa ke ranah pertambangan dikarenakan penghasilan di pertambangan lebih tinggi dan resiko yang ditanggung lebih kecil. Selain itu, setiap hari para pekerja dapat langsung memengang uang dari pekerjaan yang dilakukan, sangat berbeda dengan kegiatan bertani yang harus menunggu tiga bulan agar bisa mendapatkan uang.

Naiknya pendapatan warga dibarengi dengan semakin banyaknya kekayaan yang dimilikinya. Pendapatan yang didapatkan selain digunakan untuk memenuhi kebutuhan hidup dan membangun rumah, juga dibelajakan beberapa barang mewah seperti mobil, emas-emasan, dan lahan.

\section{Dampak lingkungan}

Eksploitasi lahan yang dilakukan selama bertahun-tahun memberikan dampak yang kurang baik pada lingkungan di Desa Keningar. Beberapa hal tersebut seperti, pertama, rusaknya lahan bekas tambang, karena ekspolitasi yang berlebihan tanpa proses reklamasi yang dilakukan. Kedua, lahan pertanian yang semakin sempit, karena lahan pertanian juga menjadi sasaran kegaiatan pertambangan. Ketiga, munculnya polusi udara dan suara. Polusi udara dan suara diakibatkan oleh adanya truk muatan pasir yang berlalu-lalang selama 24 jam penuh. Hal ini membuat semakin banyaknya debu di pemukiman dan asap truk muatan. Keempat, kerusakan jalan desa akibat truk muatan pasir. Warga mengalami ketidaknyamanan saat menggunakan jalan, terlebih lagi waktu proses evakuasi tahun 2010 pada saat merapi meletus. Keenam, Pengairan warga terganggu. beberapa sumber mata air desa mengering karena ekaploitasi alat berat yang berlebihan. Keadaan ini menjadikan debit air di irigasi semakin berkurang. Saluran irigasi desa tidak lagi sehat, debit airnya menurun, dan air tercemar oleh limbah. Kondisi air keruh, bercampur dengan debu dan Bahan Bakar Minyak (BBM). Selain hal di atas, ditemukan beberapa problem pada saliran air kecil desa yang terganggu dan rusak. Selokan-selokan yang secara normal sebagai aliran air pada waktu itu mati karena banyak pasir yang menutupi aliran. Selain itu terdapat beberapa trowongan air yang melintas di bawah jalan mengalami ambles akibat lalu-lalang truk bahan galian C. Dua hal tersebut sangat mengganggu sirkulasi air di Desa Keningar.

\section{Dampak pada keamanan ketertiban masyarakat}

Keamanan dan ketertiban masyarakat terganggu oleh ada aktivitas pertambangan pasir dengan alat berat. Pertama, Munculnya rasa takut akibat preman tambang di Desa Keningar. Preman-preman yang mengawal kegiatan pertambangan dengan alat berat memberi dampak pada menurunnya rasa aman dan rasa nyaman dalam kehidupan masyarakat desa. Konflik dengan preman tambang menumbuhkan rasa takut dalam diri masyarakat, karena perilaku preman dan ancaman-ancaman berupa tindakan kriminal sering dilontarkan ke warga desa. 
Kedua, Kamanan dan keselamatan pengguna jalan terancam. Masyarakat Desa Keningar sehari-hari menggunakan jalan utama desa untuk segala kegiatan, seperti berangkat bekerja, pergi ke lahan pertanian, berangkat sekolah, dan lain sebagainya. Kurang lebih 500 truk yang keluar masuk desa dalam satuan perhari. Hal tersebut secara langsung mengancam rasa aman masyarakat saat hendak menggunakan atau melintas di jalan tersebut. Ditambah lagi dengan perilaku supir truk yang ugal-ugalan saat mengemudi. Hal ini menjadikan resiko kecelakaan semakin tinggi.

Ketiga, Resiko keamanan dan keselamatan masyarakat di lahan pertambangan tinggi. Resiko keamanan dan keselamatan masyarakat desa di lahan pertambangan sangat tinggi. Pada saat pertambangan dengan alat berat beroperasi, banyak anak kecil yang bermain di lahan pertambangan. Tragedi kematian anak di lahan pertambangan Sungai Senowo pernah terjadi. Anak tersebut tenggelam saat bermain di kubangan bekas tambang yang terisi air. Selain itu kejadian yang beberapa kali memakan korban adalah pasca pertambangan dengan alat berat berhenti. Tragedi tersebut diamalaminoleh penambang manual yang menambang ulang lahan bekas pertambangan dengan alat berat. Srtuktur tanah yang terdiri dari gundukan bebatuan sering longsor dan memakan korban.

Keempat, Pelanggaran terhadap nilai dan norma desa. Pelanggaran terhadap nilai dan norma desa sering terlihat saat pertambangan dengan alat berat berlangsung. Pelanggran tersebut berupa minum minuman keras dan bermain perempuan di lahan pertambangan (prostitusi). Tindakan tersebut awalnya dilakukan oleh preman tambang dan sopir-sopir armada bahan galian $\mathrm{C}$, namun seiring berjalannya waktu para pemuda yang bekerja di lahan pertambangan terpengaruh dan melakukannya juga.

Penelitian ini dikaji menggunakan Teori Konflik yang diangkat dari gagasan Lawis Alfred Coser dan Ralf Dahrendorf. Gagasan Coser melalui prespektif konfliknya melihat bahwa masyarakat sebagai suatu sistem sosial yang terdiri dari berbagai komponen selalu memiliki kepentingan yang berbeda-beda, dan berusaha menaklukan komponen yang lain untuk kepentingan yang sebesar-besarnya. Hal ini terlihat pada masyarakat Desa Keningar, munculnya dua kelompok yakni kelompok pro tambang baik warga tergabung dalam struktur kehidupan perusahaan tambang maupun pengusaha tambang itu sendiri yang bersikukuh untuk selalu menambang, dan kelompok penolak pertambangan tersebut (FORPHAS/TIM 18) yang tanpa henti melakukan penolakan atau mempersempit ruang gerak pertambangan.

Konflik yang terjadi di Keningar memiliki fungsi positif dan negatif sebagaimana ditarik dari gagasan Coser. Secara positif konflik membentuk struktur masyarakat, yakni munculnya kelas menengah baru dalam masyarakat Desa Keningar. Hal ini terlihat pada saat konflik pertambangan memanas. Ciri khas kelas menangah baru adalah adanya keterampilan yang dibawa dalam sebuah profesi. Realitas pembentukan struktur baru ini dapat dilihat pada beberapa warga yang berkonflik (TIM 18) yang berhasil memperoleh kedudukan sebagai pemerintah desa (Badan Permusyawaratan Desa) karena usahanya untuk mempengaruhi perpolitikan desa. Kelas menengah baru selanjutnya adalah munculnya juragan baru di Keningar pasca pertambangan pasir dengan alat berat berhenti. Terdapat beberapa juragan pasir dalam bentuk usaha depo pasir di desa tersebut. Mereka yang semula menjadi pekerja tambang kini memiliki usaha pengelolaan bahan galian $\mathrm{C}$ secara mandiri.

Konflik di Keningar fungsional negatif, karena menyerang nilai inti masyarakat desa yang berupa menurunnya solidaritas. Solidaritas masyarakat desa menurun karena warga terpecah belah menjadi tiga golongan, yakni masyarakat pro pertambangan, masyarakat kontra pertambangan, dan masyarakat yang acuh tak acuh terhadap kegiatan pertambangan. 
Perbedaan antar golongan tersebut berdampak pada menurunnya solidaritas masyarakat, baik di kelompok seni, kegiatan gotong-royong, maupun tradisi rutinan desa seperti merti desa, kenduri, dan lain sebagainya.

\section{Ikatan Kelompok dan Pemeliharaan Fungsi-Fungsi Konflik Sosial}

Konflik dalam gagasan Coser dapat memperkuat solidaritas yang longgar. Hal ini ditemukan dalam masyarakat pada saat konflik antar kelompok kontra dan pro tambang terjadi. Menguatnya solidaritas yang longgar terlihat dalam kegiatan TIM 18 dan warga lain yang empati terhadap perjuangan TIM 18 dalam upaya penolakan terhadap kegiatan pertambangan. Konflik sosial dapat memicu solidaritas yang menghantarkan pada aliansialiansi dengan kelompok-kelompok lain. Aliansi-aliansi tersebut diwadai dalam satu forum demonstrasi masal yang melibatkan desa-desa di sekitaran Keningar dan dari kecamatan lain seperti Sawangan dan Srumbung. Melakukan aksi demonstrasi ke Kecamatan Muntilan dan ke jalan-jalan raya di kawasan tersebut. Aliansi tersebut disatukan atas dasar kepentingan dan penderitaan yang sama. Konflik berfungsi untuk berkomunikasi. TIM 18 dalam berbagai agenda penolakan maupun mempersempit ruang gerak pertambangan pasir. Bentuk riilnya adalah kegiatan musyawarah sebelum melakukan aksi atau suatutu program, seperti musyawarah sebelum demonstrasi dilakukan (baik saat demonstrasi di lingkungan pertambangan maupun di luar daerah), musyawarah terkait pembuatan portal, pemberlakukan tonase, agenda-agenda pengaduan ke berbagai instansi, dan agenda lainnya.

\section{Konflik Realistis}

Konflik realistis berasal dari kekecewaan terhadap tuntutan-tuntutan khusus yang terjadi dalam hubungan dan dari perkiraan keuntungan para partisipan. Tuntutan-tuntutan tersebut ditujukan atau diarahkan ke suatu objek yang dianggap mengecewakan atau merugikan. Pertambangan pasir dengan alat berat yang merusak dan mengganggu kenyamanan masyarakat menumbuhkan rasa kekecewaan terhadap kegiatan tersebut. Pengungkapan kekecewaan tersebut dikemas dalam beberapa bentuk seperti aksi demonstrasi, baik di lokasi pertambangan maupun di luar wilayah Keningar, portalisasi, tonase, dan pengusiran-pengusiran pertambangan di tempat-tempat terlarang. Demonstrasi di lahan pertambangan beberapa kali dilakukan oleh TIM 18 melalui pengungkapan rasa kecewa disertai tulisan-tulisan yang berisi penolakan-penolakan, hal demikian juga ditemukan dalam rangkaian deminstrasi di Kecamatan Muntilan.

\section{Permusuhan dalam hubungan sosial yang intim}

Semakin dekat hubungan seseorang, semakin besar rasa kasih sayang yang ditanamkan, maka semakin besar pula kecenderungan untuk mengungkapkan rasa permusuhan. Sedangkan dalam hubungan sekunder seperti rekan bisnis cenderung mudah dilepaskan. Masyarakat Desa Keningar dahulu terkenal memiliki solidaritas yang tinggi antar sesama. Walaupun pada akhirnya masyarakat terbelah menjadi dua kubu yang saling kontras pemahamanannya, tetapi rasa keintiman tetap terjaga. Walaupun rasa saling tidak suka antar golongan tersebut tumbuh, tetapi masyarakat desa sejauh ini lebih menekan terjadinya konflik yang secara fisik. Sedangkan dalam hubungan sekunder, seperti hubungan antara masyarakat kontra tembang dengan perusahaan tambang pasir. Konflik cenderung dilepaskan. 


\section{Kondisi-kondisi yang mempengaruhi konflik dengan kelompok luar (Out Grup) dan struktur kelompok}

Coser mengatakan bahwa konflik dengan kelompok luar dapat membantu pemantapan batas-batas struktural dalam suatu kelompok. Seperti status dan peran ketua kelompok atau koordinator dalam TIM 18 (YS). Peran YS semakin jelas sebagai seorang ketua, memobilisasi anggota, mengkoordinir, dan bertanggung jawab atas segala sesuatu yang berkaitan dengan ranah gerak TIM 18, sebagai sebuah kelompok pembela hak masyarakat dan pemerjuang keadilan lingkungan. Begitu pula anggota-anggota TIM 18, mereka bergerak sebagaimana perannya masing-masing. Hal demikian pun juga terlihat pada kelompok yang menjadi lawan, seperti kedudukan preman tambang yang melindungi atau menangkal hambatan-hambatan atau gangguan oleh warga di pertambangan. Mereka berperan layaknya keamanan yang memperlancar jalannya pertambangan.

Coser mengatakan bahwa suatu kelompok kecil yang berjuang melawan musuh, tidak akan memberikan toleransi kepada perselisihan internal. Kelompok kecil yang berjuang dalam problem ini adalah TIM 18. Sejalan dengan apa yang dikatakan oleh Coser bahwa tidak ada toleransi perselisihan TIM 18. Manajemen konflik dilakukan secara responsif oleh kelompok sebelum perselisihan internal membengkak. Secara bersama-sama TIM 18 mediskusikan dan mengambil jalan tengah sebagai sebuah solusi. Selain itu TIM 18 juga giat memperkuat ikatan internal demi mempertahankan kesatuan kelompok, dalam wujud pertemuan rutin. Jika dalam TIM 18 ada perselisihan yang terlalu berat dan tak kunjung selesai maka secara suka rela anggota tersebut keluar dari kelompok.

Selaras dengan apa yang dikatakan oleh Dahrendorf, tentang sisi ganda suatu masyarakat. Adanya gotong-royong warga dalam bentuk kerja-kerja sosial. Masyarakat desa menyebutnya dengan istilah sambatan, yakni gotong-royong dalam pembuatan atau pembenahan rumah milik warga. Dalam ruang tersebut masayarakat menyatu untuk saling tolong-menolong. Sedangkan dalam waktu yang bersamaan, masyarakat diketaui memiliki sisi konflik, seperti keberadaan TIM 18 yang memperjuangkan idealismenya dan berakir pada konflik antar warga.

Dekomposisi tenaga kerja, disini buruh tidak lagi sebagai kelompok yang homogen tunggal. Dimana buruh terampil berada di struktur atas sedangkan buruh biasa berada dibawah. Buruh tambang di dalam lingkaran kehidupan tambang tak lagi homongen seperti dahulu. Munculnya kelas menengah baru sebagaimana di sebutkan oleh Dahrendorf, yakni pekerja yang memiliki keterampilan atau spesialisasi. Kelas menengah baru menurut Dahrendorf ini berupa pekerja tambang berpindah status dari pekerja kasar ke pekerja yang terampil (operator alat berat).

Dahrendorf menyatakan bahwa ada dasar baru bagi pembentukan kelas adalah hubungan kekuasaan (authority) yang terdiri dari atasan (borjuis) dan bawahan (proletar) menyadikan unsur-unsur kelahiran kelas. Hubungan yang terbangun cukup lama antara pekerja kasar (helper) dengan operator alat berat memicu kenaikan kelas. Beberapa warga yang berstatus sebagai helper kemudian naik status ke pekerjaan yang memiliki spesialisasi atau keterampilan, yakni sebagai operator alat berat.

Dahrendorf mamandang bahwasannya terdapat perbedaan dalam masyarakat, yakni antara yang berkuasa dan yang dikuasai. Perbedaan tersebut adalah dalam konteks dominasi, antara mereka yang memiliki sedikit atau banyak kekuasaan. Perjuangan kelas yang digagas Dahrendorf lebih condong pada kekuasaan dari pada kepemilikan sarana produksi. Perjuangan kelas yang terlihat di Keningar adalah perjuangan buruh tambang yang bergabung dangan masyarakat desa dengan wadah FORPHAS/TIM 18 melawan 
pengusaha tambang. Segala bentuk perlawanan dilakukan dan akhirnya membuahkan yakni berhentinya pertambangan pasir dengan alat berat di Keningar.

\section{Kelompok Semu dan Kelompok Kepentingan}

Dalam setiap asosiasi, kepentingan kelompok penguasa merupakan nilai-nilai yang merupakan ideologi keabsahan kekuasaannya, sementara kepentingan-kepentingan kelompok bawah melahirkan ancaman bagi ideologi tersebut. Hal tersebut memicu tumbuhnya kepentingan laten dan kemunculan kelompok manifes. Kepentingan yang dinyatakan oleh Dahrendorf merupakan kepentingan yang mungkin bersifat manifes (disadari) atau laten (kepentingan potensial). Kepentingan laten dapat sewaktu-waktu muncul di permukaan dalam bentuk tujuan-tujuan yang disadari. Kepentingan laten muncul ditengah ramainya kegiatan pertambangan berjalan. Kepentingan yang tiba-tiba muncul dari segerlintir buruh tambang untuk memperjuangkan hak dan kerusakan lingkungan yang muncul, lalu diperkuat dengan FORPHAS sebagai sebuah wadah, dan berganti menjadi TIM 18. Sebagaimana dalam pemikiran Dahrendorf FORPHAS dan TIM 18 disebut sebagai kelompok manifes.

Menurut Dahrendorf, pertentangan kelas harus dilihat sebagai kelompok-kelompok pertentangan yang berasal dari struktur kekuasaan asosiasi-asosiasi yang terkoordinir secara pasti. Pertentangan kelas yang terjadi di Keningar mayoritas dilakukan oleh pekerja tambang. Para pekerja tambang mulai tersadar setelah hidup lama di lingkungan pertambangan dan melihat perubahan yang terjadi, terutama yang perubahan kondisi alam yang semakin memburuk dan hak-hak masyarakat yang tidak terpenuhi, dua hal tersebut yang menjadi dasar ideologis bagi mereka untuk bergerak melawan. Warga diwadai dalam FORPHAS/TIM 18 dan dikoordinasi dengan jelas oleh satu orang ketua atau koordinator, sehingga gerakannya terarah dan tepat sasaran.

\section{PENUTUP}

Pertambangan pasir dengan alat berat meimbukan perubanyan yang mendasar dalam masyarakat. Struktur masyarakat berubah, baik secara horizontal maupun vertikal. Perubahan status secara horizontal terdapat pada perubahan profesi buruh tani menjadi buruh tambang dan perubahan vertikal terlihat pada munculnya kelas menengah baru dalam bentuk pekerja yang memiliki spesialisasi/keterampilan, dan munculnya juragan baru (pemilik depo pasir). Perubahan budaya meliputi solidaritas masyarakat yang lemah kini menguat kembali, budaya menyimpang dan konsumerisme yang dahulu ada kini menghilang. Kondisi ekonomi masyarakat terkhusus pendapatan mengalami penurunan. Lingkungan alam di Keningar mengalami perubahan, seperti kondisi jalan desa semakin baik, polusi udara dan suara tidak lagi ada. Namun pertambangan dengan alat berat menyisakan kerusakan pada lahan bekas tambang, pengairan masyarakat terganggu dengan menurunnya debit air dan tingkat kejernihan air. Keamanan dan ketertiban masyarakat membaik, berkurangnya truk muatan pasir yang keluar masuk desa memberi rasa aman pengguna jalan, premanisme yang dahulu tumbuh kini tidak lagi ada, kebiasaan minumminuman keras dan kegiatan prostitusi di lahan tambang tidak lagi ditemukan. Namun kini resiko kecelakaan bagi penambang manual sangat tinggi. Penggunaan alat berat berdampak positif pada perubahan struktur masyarakat dan perekonomian warga, dalam bentuk kenaikan pendapatan dan munculnya struktrur baru dalam masyarakat. Namun kurang baik pada lingkungan, budaya, keamanan ketertiban masyarakat Desa Keningar. Karena condong ke arah kerusakan alam, mengancam eksistensi budaya leluhur, dan keberadaan alat berat menciptakan suasana tidak nyaman bagi warga Keningar. 


\section{DAFTAR PUSTAKA}

Akbar, Ricky. et.al. 2018. Implementasi Business Intelligence Menentukan Daerah Rawan Gempa Bumi di Indonesia dengan Fitur Geolokasi. Diunduh di http://jurnal.untan.ac.id/index.php/jepin/article/view/25518. Pada tanggal 17 November 2019

Asriningrum, Wikanti, Heru Noviar, dan Suwarsono. 2004. Penegmbangan Metode Zonasi Daerah Bahaya Letusan Gunung Api Studi Kasus Gunung Merapi. Di unduh di http://103.16.223.27/index.php/jurnal_inderaja/article/viewFile/477/408. Pada tanggal 17 November 2019

Messwati, Dyah Elok. 2012. 70 Persen Kerusakan Lingkungan akibat Operasi Tambang. Diunduh di Https://regional.kompas.com/read/2012/09/28/17313375/ 70.Persen.Kerusakan.Lingkungan.akibat.Operasi.Tambang. Pada tanggal 28 November 2019

Https://www.esdm.go.id/id/media-center/arsip-berita/miliki-127-gunung-api-aktif-jadikanindonesia-laboratorium-gunung-api-dunia. Diakses pada tanggal 28 November 2019

Idrus, Muhammad. 2009. Metode Penelitian Ilmu Sosial. Penerbit Erlangga. Yogyakarta

Ma'rifah, Risalatul ST, Nawiyanto, Ratna Endang W. 2014. Konflik Pertambangan Pasir Besi Di Desa Wogalih, Kecamatan Yosowilangun, Kabupaten Lumajang Tahun 2010-2011.

Di unduh https://jurnal.unej.ac.id/index.php/PB/article/download/584/407. Pada tanggal 17 November 2019

Moleong, Lexy J. 2014. Metodologi Penelitian Kualitatif. PT Remaja Posdakarya. Bandung

Mufid, Sofyan Anwar. 2010. Ekologi Manusia. PT Remaja Rosdakarya. Bandung

Rahadi, Dheva Vembyawan. 2018. Dampak Ekonomi dan Lingkungan Dari Aktivitas Pertambangan Pasir Di Kabupaten Magelang Pasca Penghapusan Peraturan Daerah Kabupaten Magelang Nomor 1 Tahun 2008", Studi Kasus penambangan pasir di Desa Keningar, Kecamatan Dukun, Kabupaten Magelang, Jawa Tengah. Diunduh http://etd.repository.ugm.ac.id/index.php?mod=book_detail\&sub=BookDetail\&a $\mathrm{ct}=$ view\&typ $=$ htmlext\&buku_id $=156060 \&$ obyek_id $=4 \& u n i t i d=\& j e n i s \_i d=$. Pada tanggal 7 Agustus 2019

Rahayu, et.al. 2014. Dampak Erupsi Gunung Merapi Terhadap Lahan Dan Upaya-Upaya Pemulihannya. Di unduh di https://jurnal.uns.ac.id/carakatani/article/view/13320. Pada tanggal 17 November 2019

Silalahi, Ulber. 2009. Metode Penelitian Sosial. PT Refika Aditama. Bandung

Siswono, Eko. 2015. Ekologi Sosial. Penerbit Ombak. Yogyakarta

Yudhistira, dkk. 2011. Kajian Dampak Kerusakan Lingkungan Akibat Kegiatan Penambangan Pasir Di Desa Keningar Daerah Kawasan Gunung Merapi. Di unduh

di https://ejournal.undip.ac.id/index.php/ilmulingkungan/article/view/4072. Pada tanggal 1 Desember 2019 